\title{
Застосування фізичних факторів та лікувальної фізкультури у хворих з надмірною масою тіла та ожирінням на амбулаторно-поліклінічному етапі
}

\author{
Шмакова І. П., Кафтан Т. В., Прокопчук Ю. В., Аніконова І. В.
}

Одеський національний медичний університет, м. Одеса, Україна

Актуальність. Згідно з показниками 2016 року, близько 1,1 млрд людей у світі страждають від надмірної маси тіла (НМТ) та ожиріння, що вимагає розробки ефективних підходів лікування 3 використанням комплексу фізичних факторів та лікувальної фізичної культури (ЛФК).

Мета дослідження: підвищити ефективність лікування хворих з НМТ та ожирінням шляхом застосування в комплексному лікуванні голкорефлексо- і вібровакуумтерапії з урахуванням особливостей перебігу захворювання.

Матеріали та методи. Проведено клінікоінструментальне обстеження 125 хворих з НMT та ожирінням обох статей у віці від 23 до 70 років, середній вік 45,4 $\pm 2,3$ років, які надійшли на амбулаторно-поліклінічне лікування в поліклініку № 29 м. Одеса. Всім пацієнтам визначали зріст і вагу з подальшим розрахунком індексу маси тіла (IMT), окружність талії (ОТ), показники ліпідного та коагуляційного гомеостазу, реєстрували ЕКГ, офісний артеріальний тиск (САТ, ДАТ). Проводили тестування для визначення важкості розладів харчової поведінки за допомогою модифікованого опитувальника Van Strien T. та співавторів (1986), а також вираженості апетиту і потягу до солодощів за візуальною аналоговою шкалою (ВАШ). Оцінювали динаміку змін показників якості життя. Динаміку показників якості життя оцінено за SF-36. Пацієнтам основної групі призначали дієту, ЛФК з розрахунком енергетичних витрат, голкорефлексотерапію на аурикулярні та корпоральні точки, пацієнтам групи порівняння додатково призначали вібровакуумтерапію на місця накопичення жиру.

Результати дослідження та їх обговорення. Встановлено, що комплексне застосу- вання ЛФК, голкорефлексо- та вібровакуумтерапії у хворих з НMT та ожирінням I, II та III ст. істотно підвищує ефективність лікування на амбулаторно-поліклінічному етапі за рахунок нормалізуючої дії на клінічні, антропометричні (зниження маси тіла через 3 міс. на $11,0 \%$, через 6 міс. - на 15,5\% при НMT, через 3 міс. на 7,7\%, через 6 міс. - на 9,4\% при ожирінні), показники зниження апетиту (від 5,58 $\pm 0,23$ до 2,8 $\pm 0,22$, за ВАШ $\mathrm{p}<0,001$ при НМТ; від 7,0 $\pm 0,21$ до 4,0 $\pm 0,08$, за ВАШ $p<0,001$ при ожирінні) і потягу до солодощів (від 5,03 $\pm 0,25$ до 2,5 $\pm 0,21$ за ВАШ $\mathrm{p}<0,001$ через 6 міс. при НМТ, від $5,0 \pm 0,8$ до $3,8 \pm 0,11$, за ВАШ $\mathrm{p}<0,001$ через 6 міс. при ожирінні), значного покращення харчової поведінки (розлади не реєструвалися через 6 міс. при НMT, зменшилися на 26,6\% при ожирінні), поліпшення функціонального стану нервової, серцево-судинної систем (зниження САТ, ДАТ, $\mathrm{p}<0,001$; покращення процесів реполяризації у $30,0 \%$ ), біохімічних показників і якості життя у 80,0\% хворих з НMT та ожирінням. Цей лікувальний комплекс ефективний у всіх хворих з НMT та ожирінням I, II i III cT.

Висновки. Запропоновані фізичні фактори і ЛФК у хворих з НМТ та ожирінням підвищують ефективність лікування на амбулаторно-поліклінічному етапі.

Перспективи подальших досліджень. Планується розробка нових підходів лікування вказаного контингенту хворих 3 додатковим призначенням медикаментозних препаратів.

Ключові слова: фізичні фактори, ЛФК, ожиріння, ефективність.

Конфлікт інтересів: відсутній. 